\title{
PENGGUNAAN MODEL EXPERIENTIAL LEARNING DALAM KETERAMPILAN MENULIS PARAGRAF ARGUMENTASI MAHASISWA JURUSAN PENDIDIKAN BAHASA DAN SASTRA INDONESIA
}

\author{
I. A. M. Darmayanti' ${ }^{1}$ I G. Nurjaya ${ }^{2}$, I N. Martha ${ }^{3}$, I N. Sudiana ${ }^{4}$ \\ Jurusan Pendidikan Bahasa dan Sastra Indonesia, Fakultas Bahasa dan Seni \\ Universitas Pendidikan Ganesha, Singaraja, Bali, Indonesia \\ Email: dayudarmayanti1984@yahoo.com. ${ }^{1}$
}

\begin{abstract}
The main objective of this research is to describe the achievement of the Indonesian Language Education students after using the experimental learning method in writing argumentative paragraph and also to find out the obstacles faced when using that learning method. The subject of this study were the students of Indonesian Language Education Department. The data of this study were collected by using two methods, they were assignment method and interview. The data collected were analyzed by using descriptive qualitative research design. Besides, the aims of this study are that; first, to improve the learning quality in writing argumentative paragraph. Second, this study is in order to keep the existence of experimental learning method, and the last one is to persuade and motivate the students to be more creative and innovative. The result of this study indicated that the achievement of Indonesian Language Education students when using this method was categorized in the highest level that was 90.56 points. And the obstacles found by the Indonesian Language Education students in using this experimental learning method related with their creativity in writing argumentative paragraph are that; first, they have limited information about how to organize the sentences well; second, it is hard for them to find the key words when they start to make a sentence; and the last one is that not all of them are able to use the spelling order perfectly.
\end{abstract}

Keywords: Experimental Learning Method, writing creativity, argumentative paragraph

\begin{abstract}
ABSTRAK
Penelitian ini bertujuan mendeskripsikan hasil kinerja mahasiswa saat menggunakan model experiential learning dalam keterampilan menulis paragraf argumentasi dan kendala-kendala yang dialami oleh mahasiswa jurusan Pendidikan Bahasa dan Sastra Indonesia saat menggunakan model experiential learning dalam keterampilan menulis paragraf argumentasi. Subjek penelitian ini adalah mahasiswa. Metode pengumpulan data yang digunakan adalah metode penugasan dan wawancara. Data yang diperoleh dianalisis dengan menggunakan teknik analisis deskriptif kualitatif. Penelitian ini akan memberikan berbagai manfaat, antara lain meningkatkan kualitas pembelajaran menulis paragraf argumentasi, mengeksistensikan model experiential learning, memberikan persuasi dan motivasi kepada mahasiswa untuk berpikir kritis, serta memotivasi pendidik untuk mencari alternatif pembelajaran yang lebih kreatif dan inovatif. Adapun hasil penelitian ini adalah (1) hasil kinerja mahasiswa Jurusan Pendidikan Bahasa dan Sastra Indonesia saat menggunakan model experiential learning dalam menulis paragraf argumentasi berada dalam kategori sangat baik, yaitu sebesar 90,56 dan (2) kendala-kendala yang dihadapi oleh mahasiswa Jurusan Pendidikan Bahasa dan Sastra Indonesia saat menggunakan model experiential learning dalam keterampilan menulis paragraf argumentasi adalah mahasiswa kurang memiliki kemampuan atau pengetahuan terkait mengorganisasikan kalimat dengan baik, kesulitan mencari kata kunci saat akan mengawali membuat kalimat, dan tata ejaan mahasiswa masih ada yang belum sempurna diterapkan.
\end{abstract}

Kata-kata Kunci: Model Experiential Learning, Keterampilan Menulis, Paragraf Argumentasi 


\section{PENDAHULUAN}

Pemerintah selalu berupaya menyelenggarakan pendidikan yang menyeluruh dan membumi di Indonesia. Pendidikan merupakan usaha sadar dan terencana untuk mewujudkan suasana belajar dan pembelajaran agar peserta didik secara aktif mengembangkan potensi dirinya untuk memiliki kekuatan spiritual keagamaan, pengendalian diri, kepribadian, kecerdasan, akhlak mulia, serta keterampilan yang diperlukan dirinya, masyarakat, bangsa, dan, Negara. Hal ini tertuang dalam pasal 1 ayat (1) Undang-undang Republik Indonesia Nomor 20 Tahun 2003.

Penerapan pendidikan ini dilakukan melalui pembelajaran yang dilaksanakan pada jenjang tertentu, termasuk pula pembelajaran bahasa Indonesia. Pembelajaran bahasa Indonesia di sekolah ataupun di pendidikan tinggi didasarkan atas kurikulum yang berlaku. Kurikulum merupakan sumber atau salah satu alat dalam proses pendidikan. Pemerintah melalui Kementrian Pendidikan dan Kebudayaan telah memberlakukan berbagai kurikulum pada setiap jenjang pendidikan secara serentak di seluruh wilayah Indonesia. Kurikulum ini dapat memberikan dasar-dasar pengetahuan, keterampilan, dan pengalaman belajar. Kurikulum ini dapat dikembangkan pada setiap sekolah dan juga pendidikan tinggi sesuai dengan kondisi sekolah dan pendidikan tinggi yang bersangkutan.

Selain itu, kurikulum merupakan seperangkat rencana dan pengaturan mengenai tujuan, isi, dan bahan pelajaran serta cara yang digunakan sebagai pedoman penyelenggaraan pembelajaran untuk mencapai tujuan tertentu. Kurikulum dalam pendidikan sangat memegang peranan penting. Dalam proses belajar mengajar, yang menerima proses pembelajaran adalah manusia yang sedang tumbuh dan berkembang menuju arah pendewasaan kepribadian dan penguasaan pengetahuan (Arsjad dan Mukni, 1991: 12). Demi tercapainya hal tersebut, kurikulum yang berlaku harus mampu memberikan pedoman agar bisa mencapai tujuan, termasuk dalam pembelajaran bahasa Indonesia.
Secara umum, dalam pembelajaran bahasa Indonesia, ada empat keterampilan yang berhubungan sangat erat satu sama lainnya dan perlu dikuasai untuk dapat berkomunikasi. Keempat keterampilan tersebut, meliputi keterampilan menyimak, berbicara, membaca, dan menulis.

Sebagai salah satu keterampilan berbahasa, menulis perlu diperhatikan karena merupakan keterampilan berbahasa yang bersifat produktif dan ekspresif yang sangat diperlukan untuk memenuhi kebutuhan komunikasi sehari-hari. Crimmon (dalam Rediawan, 2009: 2) menyatakan bahwa menulis merupakan suatu kegiatan yang bersifat produktif dan ekspresif. Artinya, keterampilan menulis digunakan untuk memproduksi dan mengekspresikan ide, pikiran, atau gagasan.

Sebagai keterampilan yang bersifat produktif dan ekspresif, menulis sering dikatakan sebagai keterampilan yang paling kompleks. Keterampilan menulis digunakan untuk mencatat, merekam, meyakinkan, melaporkan, menginformasikan, dan memengaruhi pembaca. Dalam kegiatan menulis, seseorang harus terampil memanfaatkan struktur bahasa dan kosa kata. Dalam pengertian, kejelasan tulisan bergantung kepada pikiran, organisasi, pemakaian, pemilihan kata, dan struktur kalimat.

Salah satu keterampilan menulis yang patut dikuasai adalah menulis paragraf argumentasi. Sesuai dengan hal itu, dapat dikatakan bahwa keterampilan menulis paragraf argumentasi merupakan keterampilan berbahasa yang sangat diperlukan dalam berkomunikasi. Dalam hal ini, dengan penguasaan keterampilan menulis, seseorang dapat mengungkapkan gagasan, pikiran, dan perasaan yang dimilikinya melalui berbagai bentuk karangan terhadap orang lain. Namun, di sisi lain, keterampilan menulis sangat kompleks karena dalam menulis, seseorang diharapkan mampu mengembangkan karangan dan juga cermat untuk memberikan informasi suatu peristiwa yang terjadi kepada pembaca dengan menggunakan bahasa yang baik dan benar. Oleh karena itu, pengembangan dan peningkatan kemampuan menulis dalam pembelajaran bahasa Indone- 
sia berpeluang besar terjadi hambatan. Hal ini sejalan dengan pendapat Trimantara (dalam Rakasiwi, 2013: 4) yang mengatakan bahwa penyebab terhadap tidak tercapainya tujuan pembelajaran menulis, meliputi (1) rendahnya tingkat penguasaan kosa kata sebagai akibat rendahnya minat baca; (2) kurangnya penguasaan mikrobahasa, seperti penggunaan tanda baca, kaidah-kaidah penulisan, diksi, penyusunan kalimat dengan struktur yang benar, dan penyusunan paragraf; (3) kesulitan menemukan metode pembelajaran menulis yang sesuai dengan kondisi dan kemampuan mahasiswa; dan (4) ketiadaan atau keterbatasan media pembelajaran menulis yang efektif.

Berdasarkan pernyataan tersebut, mahasiswa, terutama mahasiswa Jurusan Pendidikan Bahasa dan Sastra Indonesia, diharapkan mampu membuat sebuah tulisan atau menulis paragraf argumentasi dengan baik sesuai dengan tujuan pembelajaran. Kesulitan yang dialami oleh mahasiswa dalam menulis paragraf argumentasi disebabkan oleh tidak tepatnya strategi yang digunakan oleh dosen dalam mengajar. Selama melakukan aktivitas mengajar di kelas, dosen biasanya menerapkan strategi pembelajaran yang kurang inovatif, tentu mahasiswa cenderung bosan dan kurang berminat memperhatikan materi yang disampaikan sehingga mengakibatkan aktivitas belajar-mengajar kurang memadai karena tidak adanya variasi yang dilakukan oleh dosen saat mengajar di kelas. Di sinilah perlu adanya upaya untuk penyempurnaan pembelajaran, terutama dalam pemilihan model pembelajaran inovatif yang diterapkan oleh dosen dalam pembelajaran yang dapat mengembangkan keaktifan dan kreativitas mahasiswa dan memberikan kesempatan kepada mahasiswa untuk lebih banyak belajar sendiri serta mengungkapkan berbagai gagasannya dalam menemukan idenya. Salah satu alternatifnya, yaitu dengan menerapkan model experiential learning.

Model experiential learning adalah suatu model pembelajaran yang mengonstruksi pengetahuan melalui pengalaman. Pembelajaran akan lebih terpusat pada pengalaman-pengalaman belajar mahasiswa yang bersifat terbuka dan mahasiswa mampu membimbing diri sendiri sehingga pengalaman tersebut bisa dituangkan ke dalam sebuah tulisan. Model pembelajaran ini dipilih dalam pembelajaran menulis paragraf argumentasi karena melalui model pembelajaran ini pembelajaran akan lebih bermakna dan membumi bagi mahasiswa sehingga tidak lagi hanya terfokus pada dosen. Model experiential learning ini menekankan yang dialami, dilihat, dan yang dipahami oleh mahasiswa sendiri, bukan orang lain. Konsep ini sejalan dengan paragraf argumentasi karena dalam paragraf itu menceritakan pengalaman yang pernah dilalui oleh seseorang secara kronologis. Dengan cara ini dapat mengarahkan para mahasiswa dalam hal memperoleh lebih banyak pengalaman dengan cara keterlibatan secara aktif dan personal daripada mahasiswa banyak melihat materi atau konsep.

Dengan demikian, penelitian yang berjudul "Penggunaan Model Experiential Learning dalam Keterampilan Menulis Paragraf Argumentasi Mahasiswa Jurusan Pendidikan Bahasa dan Sastra Indonesia (PBSI)" ini memiliki otoritas yang tinggi sebagai sebuah penelitian yang harus dilakukan. Penelitian ini dilakukan dengan tujuan (1) untuk mendeskripsikan hasil kinerja mahasiswa Jurusan PBSI saat menggunakan model experiential learning dalam keterampilan menulis paragraf argumentasi dan (2) untuk mendeskripsikan kendala-kendala yang dihadapi oleh mahasiswa Jurusan PBSI saat menggunakan model experiential learning dalam keterampilan menulis paragraf argumentasi.

\section{METODE}

Rancangan penelitian yang digunakan dalam penelitian ini adalah rancangan deskriptif kualitatif. Dengan menggunakan rancangan deskriptif, ada tiga tahap yang harus dilewati, yakni: (1) tahap pendahuluan atau sering disebut tahap pengolahan data, (2) tahap pengorganisasian data, dan (3) tahap penemuan hasil (Wignjosoebroto, dalam Suandi, 2008: 65).

Subjek penelitian ini adalah mahasiswa jurusan Pendidikan Bahasa dan Sastra 
Indonesia. Objek penelitian ini adalah hasil kinerja mahasiswa saat menggunakan model experiential learning dalam keterampilan menulis paragraf argumentasi dan kendala-kendala yang dialami oleh mahasiswa saat menggunakan model ini.

Metode pengumpulan data merupakan langkah yang paling utama dalam penelitian. Berangkat dari asumsi itu, teknik pengumpulan data yang digunakan dalam penelitian ini adalah metode penugasan dan wawancara. Metode tugas dan resitasi adalah suatu cara penyajian pelajaran dengan cara pendidik/pengajar memberi tugas tertentu kepada peserta didik dalam waktu yang telah ditentukan dan peserta didik mempertanggungjawabkan tugas yang dibebankan kepadanya (Usman dan Setiawati, 1993: 125). Dengan memakai metode ini, data hasil kinerja mahasiswa dalam menulis paragraf argumentasi yang menggunakan model experiential learningg akan tercapai sesuai dengan harapan, sedangkan metode wawancara dalam penelitian ini bertujuan mengklarifikasi dan melengkapi data yang telah diperoleh dalam observasi. Sesuai dengan metode yang digunakan dalam penelitian ini, digunakan instrumen berupa penugasan dan pedoman wawancara tidak terstruktur.

Data-data yang telah dikumpulkan menggunakan instrumen yang ada, selanjutnya akan dianalisis menggunakan metode analisis data. Analisis data ini menggunakan metode analisis deskriptif kualitatif dan kuantitatif. Berdasarkan teori analisis data, penelitian ini mengikuti prosedur, yaitu: reduksi data, penyajian data dan penyimpulan data. Reduksi data merupakan proses berpikir sensitif yang memerlukan kecerdasan, keluasan, dan kedalaman wawasan yang tinggi (Sugiyono, 2007: 339). Dalam penelitian ini, peneliti memilih data-data yang sesuai dengan masalah, sedangkan data yang dianggap tidak penting diabaikan. Setelah data digolongkan, selanjutnya data diolah dan dianalisis untuk memperoleh jawaban yang tepat sesuai dengan rumusan masalah sehingga data tersebut dapat menjawab permasalahan yang diangkat dalam penelitian ini. Dalam penyajian data ini, data yang didapat dihubungkan dengan teori- teori yang relevan, yang nantinya dapat menjawab permasalahan yang ingin dipecahkan. Untuk mengetahui keakuratan penelitian, penyimpulan sangat penting dilakukan. Penyimpulan yang dilakukan harus dapat menjawab semua masalah yang diangkat dalam penelitian tersebut sehingga hasil akhirnya diperoleh informasi mengenai kendala-kendala yang dialami oleh mahasiswa dalam menulis paragraf argumentasi.

\section{HASIL DAN PEMBAHASAN}

\section{Hasil Penelitian}

Hasil penelitian meliputi (1) hasil kinerja mahasiswa Jurusan Pendidikan Bahasa dan Sastra Indonesia saat menggunakan model experiential learning dalam keterampilan menulis paragraf argumentasi dan (2) kendala-kendala yang dihadapi oleh mahasiswa Jurusan Pendidikan Bahasa dan Sastra Indonesia saat menggunakan model experiential learning dalam keterampilan menulis paragraf argumentasi. Hasil analisis menunjukkan bahwa hasil kinerja mahasiswa Jurusan Pendidikan Bahasa dan Sastra Indonesia saat menggunakan model experiential learning dalam keterampilan menulis paragraf argumentasi tergolong sangat baik. Dalam hal ini, sebagian besar mahasiswa mampu menulis paragraf argumentasi dengan menggunakan model pembelajaran berbasis pengalaman. Namun, ada beberapa mahasiswa yang masih tergolong cukup dalam menulis paragraf argumentasi dengan menggunakan model pembelajaran ini. Adapun rincian skor hasil kinerja mahasiswa dijabarkan pada tabel 1 di halaman berikut. 
Tabel 1: Skor Hasil Kinerja Mahasiswa dalam Menulis Paragraf Argumentasi

\begin{tabular}{|c|l|c|}
\hline No. & \multicolumn{1}{|c|}{ Nama Mahasiswa } & $\begin{array}{c}\text { Skor } \\
\text { Hasil } \\
\text { Kinerja }\end{array}$ \\
\hline 1 & Arnum Hardiyanti Anjani & 97 \\
\hline 2 & Ni Putu Purnamiati & 92 \\
\hline 3 & I Wayan Sugiarta & 95 \\
\hline 4 & Ermina Nurjaya & 82 \\
\hline 5 & Ni Nyoman Mei Artini & 88 \\
\hline 6 & Putu Devi Arys Setia Hati & 91 \\
\hline 7 & Ni Nyoman Ayu Maharani & 96 \\
\hline 8 & Ni Jro Putu Oktavia Suwartami & 88 \\
\hline 9 & Warina & 86 \\
\hline 10 & Kadek Suriani & 90 \\
\hline 11 & Rika Citra Astuti & 92 \\
\hline 12 & Okvita Sari & 93 \\
\hline 13 & Gusti Ayu Cintya Pramita & 88 \\
\hline 14 & I Putu Agus Ari Satria Putra & 95 \\
\hline 15 & Komang Gunarianta & 89 \\
\hline 16 & Ni Made Novia Lestari & 89 \\
\hline 17 & Riana Cipta Somantari & 88 \\
\hline 18 & Gamma Uswatun Hasanah & 87 \\
\hline 19 & Dinda Vida Miranda & 90 \\
\hline 20 & Ni Putu Eva Cahaya Dewi & 93 \\
\hline 21 & Made Arya Sistadewi & 91 \\
\hline 22 & Moh. Nanang Qosim & 87 \\
\hline 23 & Muhammad Imam Hilmi & 90 \\
\hline 24 & I Gede Helmi Supradifta & 95 \\
\hline 25 & Iffah Faridatul Hasanah & 92 \\
\hline & & $\mathbf{2 2 6 4}$ \\
\hline & & $\mathbf{9 0 , 5 6}$ \\
\hline
\end{tabular}

Berdasarkan tabel di atas, terlihat jelas mahasiswa mampu menulis paragraf argumentasi dengan menggunakan model experiential learning. Pemberian skor hasil kinerja mahasiswa ini dilihat berdasarkan atas penilaian terhadap 5 hal, yakni isi, organisasi, kosakata, tata bahasa, dan ejaan.

Hasil analisis menyatakan bahwa di antara 25 orang mahasiswa, 1 orang mendapatkan nilai 97 (4\%), 1 orang mendapatkan nilai 96 (4\%), 3 orang mendapatkan nilai 95 (12\%), 2 orang mendapatkan nilai $93(8 \%), 3$ orang mendapatkan nilai 92 (12\%), 2 orang mendapatkan nilai $91(8 \%), 3$ orang mendapatkan nilai $90(12 \%), 2$ orang mendapatkan nilai 89 $(8 \%), 4$ orang mendapatkan nilai $88(16 \%), 2$ orang mendapatkan nilai $87(8 \%)$, dan 1 orang mendapatkan nilai $86(4 \%)$ dengan predikat sangat baik, sedangkan 1 orang mahasiswa mendapatkan nilai $82(4 \%)$ dengan predikat baik. Secara keseluruhan, hasil kinerja mahasiswa saat menggunakan model pembelajaran ini dalam menulis paragraf argumentasi, yaitu sangat baik. Sesuai dengan pedoman konversi skala penilaian, rentangan skor 86-100 dinyatakan dalam kategori sangat baik. Jadi, hasil kinerja mahasiswa saat menggunakan model experiential learning dalam menulis paragraf argumentasi berada dalam kategori sangat baik, yaitu sebesar 90,56.

Berdasarkan hasil wawancara dengan mahasiswa, ditemukan beberapa kendala yang dialami oleh mereka saat menulis paragraf argumentasi, antara lain sebagai berikut. (1) Mahasiswa kurang memiliki kemampuan atau pengetahuan terkait mengorganisasikan kalimat dengan baik. (2) Mahasiswa kesulitan mencari kata kunci saat akan mengawali membuat kalimat. (3) Tata ejaan mahasiswa masih ada yang belum mampu menerapkan dengan baik.

\section{Pembahasan}

Dari uraian hasil penelitian di atas, terdapat beberapa hal yang dipandang penting sehubungan dengan kemampuan menulis paragraf argumentasi. Pembahasan hasil penelitian difokuskan pada temuan-temuan penting yang dapat meningkatkan kemampuan menulis paragraf argumentasi pada mahasiswa Jurusan Pendidikan Bahasa dan Sastra Indonesia dengan penerapan model experiential learning. Temuan-temuan tersebut, yakni (1) hasil kinerja mahasiswa Jurusan Pendidikan Bahasa dan Sastra Indonesia saat menggunakan model experiential learning dalam menulis paragraf argumentasi dan terdapat (2) kendala-kendala yang dihadapi oleh mahasiswa Jurusan Pendidikan Bahasa dan Sastra Indonesia saat menggunakan model experiential learning dalam keterampilan menulis paragraf ar- 
gumentasi Temuan-temuan tersebut diuraikan sebagai berikut.

Temuan pertama adalah hasil kinerja mahasiswa Jurusan Pendidikan Bahasa dan Sastra Indonesia saat menggunakan model experiential learning dalam menulis paragraf argumentasi yang berada dalam kategori sangat baik, yaitu sebesar 90,56. Ini membuktikan bahwa mahasiswa ini memiliki kemampuan yang mumpuni dalam menulis paragraf argumentasi. Ada beberapa hal yang menyebabkan mereka mampu menulis paragraf argumentasi, antara lain pemberian bimbingan dan penghargaan oleh pendidik dapat mendorong mahasiswa menjadi lebih aktif. Pendidik memiliki peranan yang sangat penting dalam keseluruhan proses pembelajaran. Upaya pendidik dalam membimbing mahasiswa harus didasari dengan kesabaran dan keikhlasan. Pendidik harus tetap menghargai usaha mahasiswa, baik yang belum berhasil maupun yang sudah berhasil. Bimbingan yang diberikan oleh pendidik dalam menulis paragraf argumentasi dapat mempermudah mahasiswa dalam memahami pelajaran yang diberikan. Kesulitan yang dialami oleh mahasiswa dalam pembelajaran dapat segera teratasi karena bimbingan yang diberikan oleh pendidik. Pendidik mampu memotivasi mereka untuk belajar. Djamarah (2002: 182) menyatakan bahwa "Motivasi memegang peranan penting dalam belajar. Seorang tidak akan dapat belajar dengan baik dan tekun jika tidak ada motivasi dalam dirinya. Bahkan, tanpa motivasi, seseorang tidak akan melakukan kegiatan belajar. Oleh karena itu, pendidik perlu memberikan motivasi kepada peserta didik selama proses belajar berlangsung. Selain itu, pendidik juga memegang peranan penting dalam memengaruhi peningkatan hasil belajar siswa.

Temuan penting kedua adalah adanya kendala-kendala yang dihadapi oleh mahasiswa Jurusan Pendidikan Bahasa dan Sastra Indonesia saat menggunakan model experiential learning dalam keterampilan menulis paragraf argumentasi adalah mahasiswa kurang memiliki kemampuan atau pengetahuan terkait mengorganisasikan kalimat dengan baik, kesulitan mencari kata kunci saat akan mengawali membuat kalimat, dan tata ejaan mahasiswa masih ada yang belum sempurna diterapkan. Terkait dengan kendala-kendala itu, ada beberapa solusi yang dapat dilakukan untuk mengatasi hal itu, di antaranya: melatih mahasiswa untuk menyusun kalimat yang baik dan benar secara kontinu, menugasi mahasiswa untuk membaca dan menghafalkan serta mengaplikasikan aturan pemakaian tanda baca atau segala sesuatu yang berhubungan dengan ejaan, serta memotivasi mahasiswa dalam menulis paragraf argumentasi. Mudjiono (2006: 85) menyatakan bahwa motivasi memiliki manfaat untuk membangkitkan, meningkatkan, dan memelihara semangat siswa untuk belajar sampai dengan berhasil. Dalam penelitian ini, pendidik (dosen) mulai memberikan motivasi kepada mahasiswa saat mengalami hambatan atau kendala. Motivasi yang diberikan oleh pendidik tidak hanya di depan kelas tetapi langsung mendekati dan berkomunikasi dengan mahasiswa.

\section{SIMPULAN DAN SARAN}

Berdasarkan latar belakang dan hasil penelitian, diperoleh dua simpulan yang dapat peneliti ambil. Pertama, hasil kinerja mahasiswa Jurusan Pendidikan Bahasa dan Sastra Indonesia saat menggunakan model experiential learning dalam menulis paragraf argumentasi berada dalam kategori sangat baik, yaitu sebesar 90,56. Kedua, kendala-kendala yang dihadapi oleh mahasiswa Jurusan Pendidikan Bahasa dan Sastra Indonesia saat menggunakan model experiential learning dalam keterampilan menulis paragraf argumentasi adalah mahasiswa kurang memiliki kemampuan atau pengetahuan terkait mengorgan is a sikan kalimat dengan baik, kesulitan mencari kata kunci saat akan mengawali membuat kalimat, dan tata ejaan mahasiswa masih ada yang belum sempurna diterapkan.

Ada beberapa saran yang dapat dibuat dalam penelitian ini. Pertama, dosen bahasa Indonesia diharapkan mampu memotivasi mahasiswa sehingga dapat menghasilkan kinerja yang baik dalam menulis paragraf, khususnya paragraf argumentasi. Kedua, penggunaan 
model experiential learning yang tepat dapat meningkatkan keterampilan menulis paragraf argumentasi pada mahasiswa Jurusan Pendidikan Bahasa dan Sastra Indonesia. Berkenaan dengan hal itu, peneliti lainnya sangat diharapkan untuk melakukan penelitian mengenai model ini dari aspek lain yang dianggap penting untuk dikaji.

\section{DAFTAR PUSTAKA}

Arsjad, Maidar. G. dan Mukti U.S. 1991. Pembinaan Kemampuan Berbahasa Indonesia. Jakarta: Erlangga.

Rakasiwi, A.A. Ratna. 2013. Penggunaan Media Brosur Perjalanan Wisata Sebagai Strategi untuk Meningkatkan Keterampilan Menu lis Karangan Narasi Siswa Kelas X.1 SMA Saraswati Singaraja. Skripsi (tidak diterbitkan). Jurusan PBSI, UNDIKSHA.

Suandi, Nengah. 2008. Pengantar Metodologi Penelitian Bahasa. Singaraja: Universitas Pendidikan Ganesha.

Sugiyono. 2007. Metode Penelitian Pendidikan. Bandung: Alfabet.

Undang-undang Nomor 20 Tahun 2003. Sistem Pendidikan Nasional. Jakarta.

Usman, Uzer dan Lilis Setiawati. 1993. Upaya Optimalisasi Kegiatan Belajar Mengajar. Bandung: Rosda Karya. 